\title{
Implementasi Metode Profile Matching dalam Pembuatan Tes Psikologi untuk Pemetaan Karir Berdasarkan Minat dan Kepribadian
}

\author{
Arifi Zulaika1, Agus Sidiq Purnomo \\ ${ }^{1,2}$ Informatika, Fakultas Teknologi Informasi, Universitas Mercu Buana Yogyakarta, Indonesia \\ Email: 1arifi.aa84@gmail.com, ${ }^{2}$ sidiq@ mercubuana-yogya.ac.id
}

\begin{abstract}
Abstrak
Minat dan kepribadian sangat penting untuk diketahui oleh masing-masing orang. Hampir dipastikan jika seseorang mengetahui minat dan kepribadian yang tepat maka ia tak akan salah melangkah ke jalan karir yang bukan menjadi minat dan kepribadian yang ada dalam dirinya. Pada saat ini alat yang dapat memetakan minat dan kepribadian hanya dapat dilakukan melalui tes psikologi. Khususnya pada penelitian ini melakukan pengembangan tes psikologi menjadi terkomputerisasi. Pengembangan tes menjadi digital perlu dilakukan untuk memperoleh hasil yang cepat, maksimal, dan akurat. Hasil penelitian ini adalah berupa hasil pemeriksaan psikologis yang berisi tentang hasil pemetaan minat, pemetaan kepribadian dan rekomendasi bidang karir yang cocok untuk peserta tes berdasarkan dari sisi psikologis peserta tes. Metode penelitian yang diterapkan menggunakan metode waterfall. Pengembangan tes psikologi minat dan kepribadian menggunakan model CBT (Computer Based Test) yang berisi tes minat (RIASEC) dan tes kepribadian (DISC). Tes minat menggunakan teori Holland, sedangkan tes kepribadian menggunakan teori Marston. Sistem ini diisi dengan 31 data karir. Untuk menghasilkan karir pada masing-masing peserta tes menggunakan metode profile maching atau biasa disebut group algorithm programing (GAP) yang dikombinasikan nilai tes minat dan nilai tes kepribadian. Sistem telah diuji coba dengan 50 peserta tes dan hasil telah divalidasi oleh pakar (Psikolog). Hasilnya didapatkan $90 \%$ hasil karir valid dan 10\% tidak valid, yang menunjukan bahwa aplikasi sistem pakar ini sangat efektif.
\end{abstract}

Kata kunci: GAP, Holland, Kepribadian, Marston, Minat, Sistem Pakar, Profile Matching, Waterfall

\section{Implementation of Profile Matching Method in Making Psychological Tests for Career Mapping Based on Interest and Personality}

\begin{abstract}
Interests and personality are very important for each person to know. It is almost certain that if someone knows the right interests and personality then he will not go wrong to step into a career path that is not the interest and personality that is in him. At this time a tool that can map interests and personality can only be done through psychological tests. In particular, in this study, psychological tests were developed to become computerized. The development of tests to be digital needs to be done to obtain fast, maximum, and accurate results. The results of this study are in the form of psychological examination results containing the results of interest mapping, personality mapping and career field recommendations that are suitable for test participants based on the psychological side of test participants. The research method applied is the waterfall method. Development of psychological tests of interest and personality using the CBT (Computer Based Test) model which contains an interest test (RIASEC) and a personality test (DISC). The interest test uses Holland's theory, while the personality test uses Marston's theory. This system is filled with 31 career data. To produce a career for each test taker using the profile maching method or commonly called group algorithm programming (GAP) which is combined with interest test scores and personality test scores. The system has been tested with 50 test takers and the results have been validated by experts (Psychologists). The result is that $90 \%$ of career results are valid and $10 \%$ are invalid, which shows that the application of this expert system is very effective.
\end{abstract}

Keywords: Expert System, GAP, Holland, Interests, Personality, Profile Matching, Waterfall

\section{PENDAHULUAN}

Minat dan kepribadian adalah hal pasti yang dimiliki oleh setiap individu. Dalam hal ini minat dan kepribadian yang berkaitan dengan perencanan masa depan. Beberapa individu mungkin sudah dapat menyadari 
tentang minat atau kepribadian apa yang timbul pada dirinya, akan tetapi ada juga beberapa individu yang tidak mengetahui minat atau kepriibadian apa yang tertanam pada dirinya.

Perkembangan teknologi informasi membuat semua proses harus bisa menjadi cepat, tepat dan akurat. Dalam hal ini yaitu bidang psikolgi dalam pengembangan tes minat dan kepribadian yang masih menggunakan media kertas sebagai alat tes psikologi. Pada penelitian ini mengambil studi kasus di lembaga psikologi Detection yogyakarta dalam pengembangan alat tes psikologi.

Tes minat dan kepribadian yang masih menggunakan media kertas dalam pengerjaanya tidak jarang menalami kendala baik itu dalam pengerjaan atau dalam pengoreksian hasilnya. Oleh karena itu, pada penelitian ini dikembangkan sebuah platform tes psikologi pemetaan minat dan kepribadian berbasis CBT (Computer Based Test) yang berisi tes minat dan tes kepribadian.

Minat merupakan landasan penting bagi seseorang untuk melakukan kegiatan dengan baik yaitu dorongan seseorang untuk berbuat. Secara bahasa minat berarti kecenderungan hati yang tinggi terhadap sesuatu. Minat merupakan sifat yang relatif menetap pada diri seseorang. Minat besar sekali pengaruhnya terhadap kegiatan seseorang sebab dengan minat ia akan melakukan sesuatu yang diminatinya. Sebaliknya tanpa minat seseorang tidak mungkin melakukan sesuatu [1].

Kepribadian sangatlah penting untuk diketahui setiap orang agar setiap individu mampu mengembangkan kelebihan yang dimilikinya. Seseorang yang kesulitan dalam mengembangkan dirinya kemungkinan karena tidak mengetahui sama sekali kelemahan dan kekurangan yang dimilikinya [2].

Seseorang yang kesulitan dalam mengembangkan dirinya kemungkinan karena tidak mengetahui sama sekali kelemahan dan kekurangan yang dimilikinya. Menurut Holland \& Alkhelil, individu yang berkarir sesuai dengan kecenderungan profil kepribadian yang dimiliki, akan nyaman beraktivitas atau bekerja di lingkungannya. Holland juga meyakini bahwa pemilihan pekerjaan merupakan ekspansi kepribadian dan usaha untuk mengungkapkan diri di dunia pekerjaan [3]

Tidak semua orang tahu apa yang menjadi minat dirinya. Sehingga perlu konsultasi ke psikolog, tetapi mahalnya biaya konsultasi dan lamanya hasil deteksi minat menyebabkan orang enggan untuk mendeteksi minat dan bakart mereka. Minat dan bakat sangat penting dalam menentukan jurusan kuliah, profesi ataupun pekerjaan pekerjaan. Sistem pakar untuk pendeteksian minat dan bakat adalah salah satu alternatif yang ditempuh untuk memecahkan permasalahan tersebut. Salah satu model yang digunakan untuk pendeteksian minat dan bakat adalah model RIASEC [4].

Karakter diri terbentuk dari dua faktor, yaitu faktor keturunan dan faktor lingkungan. Faktor keturunan akan membentuk karakter yang disebut dengan karakter natural yang dipengaruhi oleh orang tua biologis individu. Sedangkan faktor lingkungan dipengaruhi oleh lingkungan seseorang tumbuh. Kedua hal tersebut menimbulkan dua karakter pada diri individu, sehingga seseorang dapat memiliki karakter yang berbeda ketika berada di rumah dan di lingkungan [5].

Karir adalah salah satu hal penting yang perlu disiapkan dalam kehidupan seseorang. Perencanaan karir idealnya dilakukan pada masa remaja. Meskipun demikian, banyak siswa SMA masih belum bisa menentukan dan mengambil keputusan tentang pemilihan studi lanjut di Perguruan Tinggi. Pada penelitian ini, prototype psikotes yang akan dikembangkan adalah tes perencanaan karir. Tes perencanaan karir menggunakan model CBT (Computer Base Test) yang berisi tes kognitif (bakat) dan tes minat. Bentuk dari tes kognitif adalah multiple choice menggunakan teori Sternberg. Bentuk dari tes minat adalah forced choice menggunakan teori Holland [6].

Berdasarkan penelitian Gambaran kepribadian berdasarkan tes DISC mahasiswa Fakultas Kedokteran Universitas Sam Ratulangi Manado semester 1 tahun 2016, penelitian dilakukan untuk mengetahui gambaran kepribadian berdasarkan tes DISC mahasiswa Fakultas Kedokteran Universitas Sam Ratulangi semester 1 tahun 2016. Sebagai responden pada penelitian yaitu keseluruhan populasi mahasiswa Fakultas Kedokteran Universitas Sam Ratulangi semester 1 tahun 2016 yang telah memenuhi kriteria inklusi berjumlah 101 orang [7].

Berdasarkan penelitian Implementasi Metode Profile Matching Untuk Evaluasi Potensi Akademik Penjurusan Siswa MAN 2 Kota Kediri, penelitian menggunakan metode profile matching untuk evaluasi potensi akademik penjurusan siswa. Metode profile matching digunakan dengan menganalisa kriteria penilaian akademik dan non akademik. Kriteria nilai akademik meliputi nilai rata-rata raport dan nilai Ujian Nasional sedangkan data nilai non akademik siswa meliputi minat siswa, minat orang tua, tes IQ dan catatan prestasi siswa. Adapun rekomendasi jurusan meliputi jurusan IPA, IPS dan Bahasa. Selanjutnya kriteria penilaian disesuaikan dengan nilai gap kompetensi jurusan berdasarkan kategori core factor dan secondary factor [8].

Berdasarkan Sistem Pakar Pengembangan Skala Minat Karir Mahasiswa dengan Inferensi Fuzzy Tsukamoto, pola minat juga menjadi salah satupenentu keberhasilan karyawan dalam dunia kerja ditentukan oleh sikap dan kemampuan, akan tetapi kepuasan seseorang dalam bekerja menjadi lebih tinggi jika karir tersebut sesuai dengan minatnya. Sampai saat ini masih banyak pelamar kerja yang memilih pekerjaan tanpa melihat kemampuan dan minat yang dimiliki. Sistem menggunakan parameter- 
parametertertentu yang kemudian nantinya dapat memberikan kemudahan bagi pengguna untuk memilih pekerjaan sesuai dengan minat dan kemampuan yang dimiliki. [9].

Berdasarkan Sistem Pakar Deteksi Karakteristik dan Kepribadian Diri Menggunakan Metode Forward Chaining, dimana setiap perserta yang mengikuti tes kepribadian akan menjawab fakta yang sesuai dengan masing-masing peserta dari pertanyaan yang disajikan pada aplikasi, kemudian sistem akan bekerja dengan melakukan pencarian kesimpulan berdasarkan aturan (rule) yang telah ditetapkan pada sistem. Aplikasi berbasis website "Who Am I?" dapat membantu mengatasi keterbatasan psikolog dalam menerjemahkan kemampuannya ke dalam suatu aplikasi yang dapat diakses dengan mudah. [10].

\section{METODE PENELITIAN}

Metode penelitian yang diterapkan pada penelitian ini adalah dengan pengembangan metode waterfall. Metode waterfall merupakan model pengembangan sistem informasi yang sistematik dan sekuensial. Metode Waterfall memiliki 6 tahapan yaitu (1) Analyst, (2) Design, (3) Implementation, (4) Testing, (5) Development, (6 Maintenance). Desain jalannya penelitian dapat dilihat pada Gambar 1.

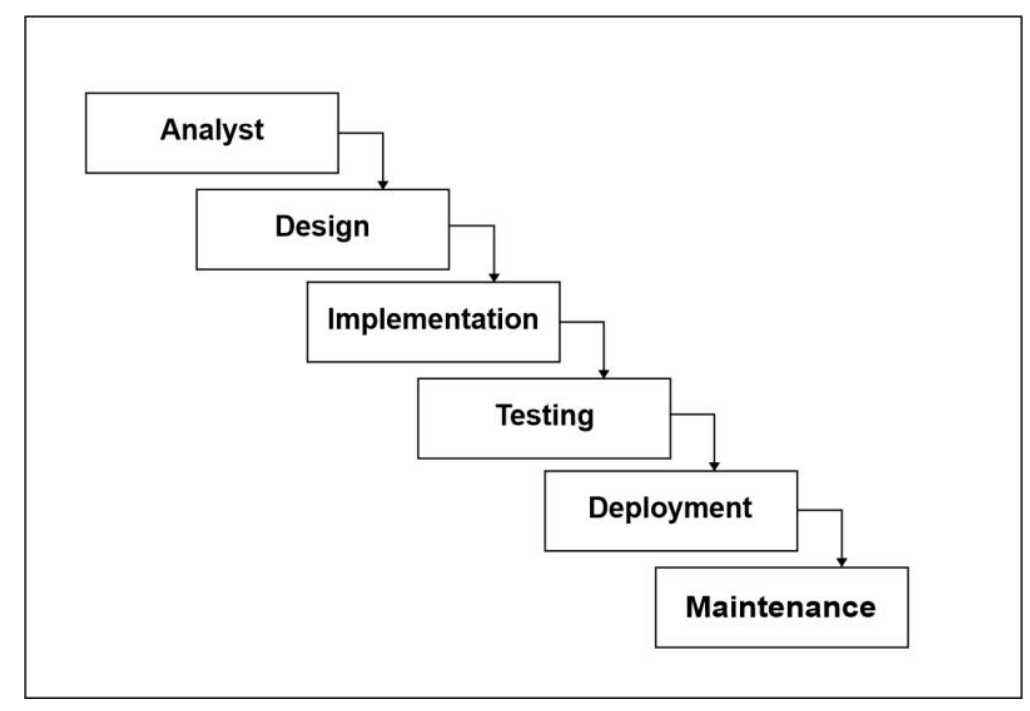

Gambar 1. Metode Waterfall

Analyst merupakan kegiatan pengumpulan informasi dan data diperoleh dengan diskusi, dan observasi. Dalam kasus ini peneliti melakukan diskusi dengan Psikolog (pakar) dan observasi jalanya tes psikologi secara manual.

Design merupakan kegiatan perancangan seluruh kebutuhan sistem yaitu: flowchart, context diagram, data flow diagram, entity data relationship, user interface.

Implementation merupakan kegiatan merealiasaikan serangkaian program atau unit program. Kemudian pengujian unit melibatkan verifikasi bahwa setiap unit program telah memenuhi spesifikasinya. Pada tahap ini juga sistem tes akan dibuat

Testing merupakan kegiatan pengujian fungsi sistem sebelum sistem di launcing. Pengujian yang dilakukan seperti security testing, function testing, atau hal lainya untuk memastikan sistem berjalan dengan benar.

Development merupakan kegiatan yang pada di penelitian ini adalah melakukan upload sistem ke web hosting. Hal ini diperlukan agar sistem bisa diakses secara online.

Maintenance adalah kegiatan pembetulan kesalahan yang tidak ditemukan pada tahapan-tahapan sebelumnya, meningkatkan implementasi dari unit sistem, dan meningkatkan layanan sistem sebagai kebutuhan baru.

\section{HASIL DAN PEMBAHASAN}

\subsection{User Interface}

Berdasarkan diskusi dengan pakar (Psikolog) tampilan antar muka atau desain user interface maka akan dibuat 3 halaman utama dalam sistem tes. 3 halaman tes yaitu adalah halaman landing page, halaman peserta tes, dan halaman admin tes. 
a. Halaman landing page, pada halaman ini dirancang untuk mengarahkan user ke arah untuk melakukan tes dan pentingnya mengenali minat dan kepribadian seseorang. Berikut adalah tampilan desain antar muka pada halaman landing page yang tertera pada Gambar 2.

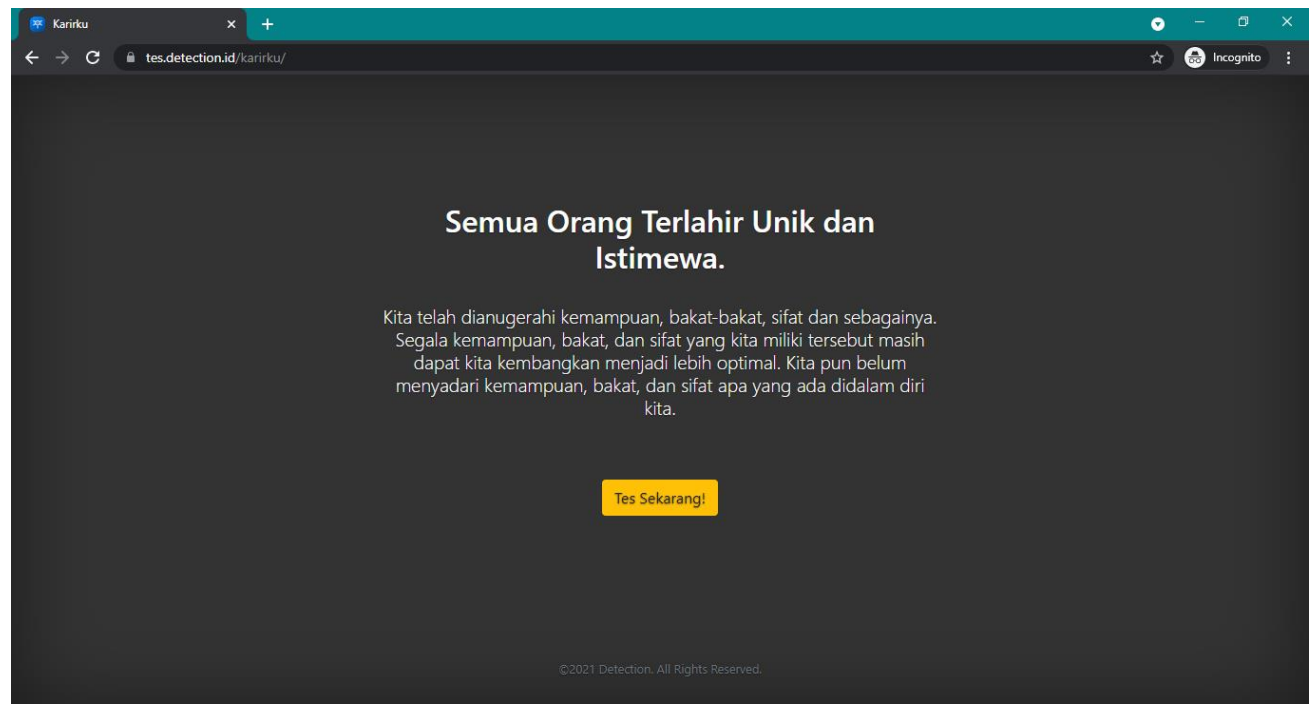

Gambar 2. Halaman Landing Page

b. Halaman peserta tes, Halaman ini adalah halaman yang digunakan untuk mengerjakan tes. Pilihan jawaban menggunakan radio button.

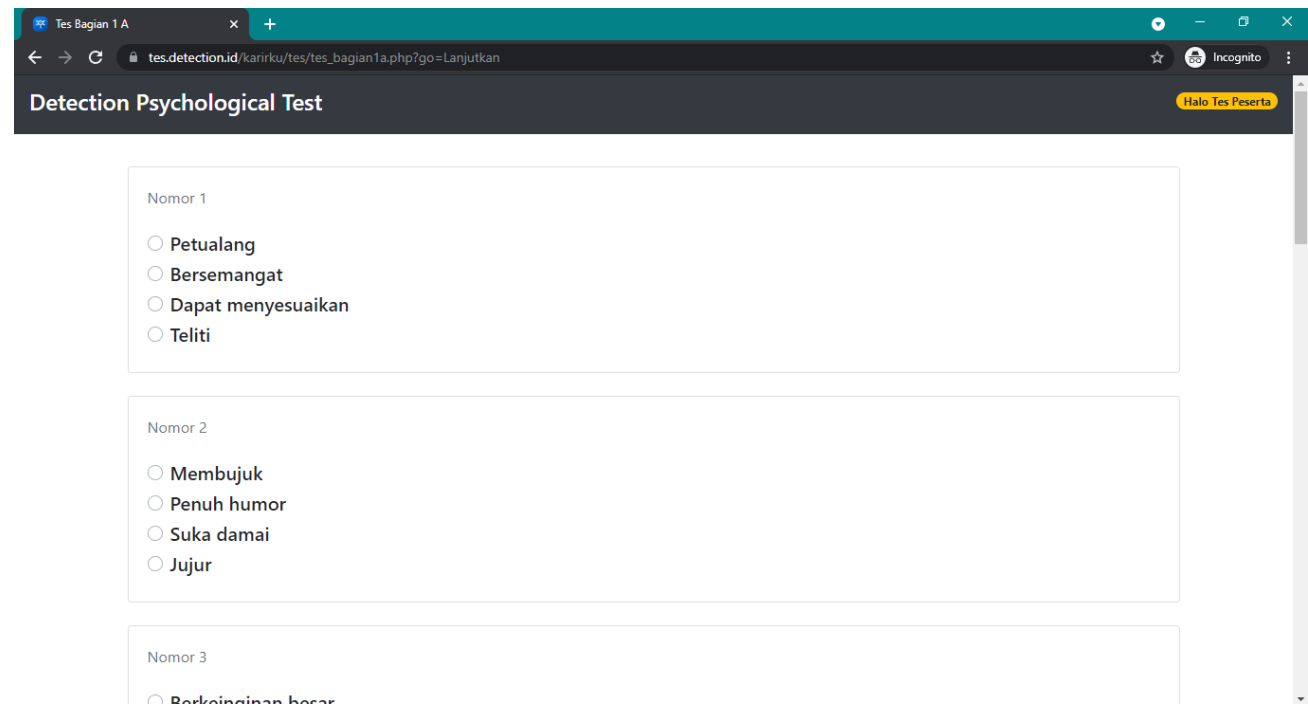

Gambar 3. Halaman Registrasi Tes

c. Halaman utama ketiga adalah halaman admin tes. Secara umum halaman admin ini berisi semua hal-hal penting terkait dengan data peserta tes, penjadwalan tes, data karir, data pembobotan, data penilaian, data soal tes minat, dan data soal tes kepribadian. Untuk halaman pertama pada halaman admin adalah halaman dashboard. 


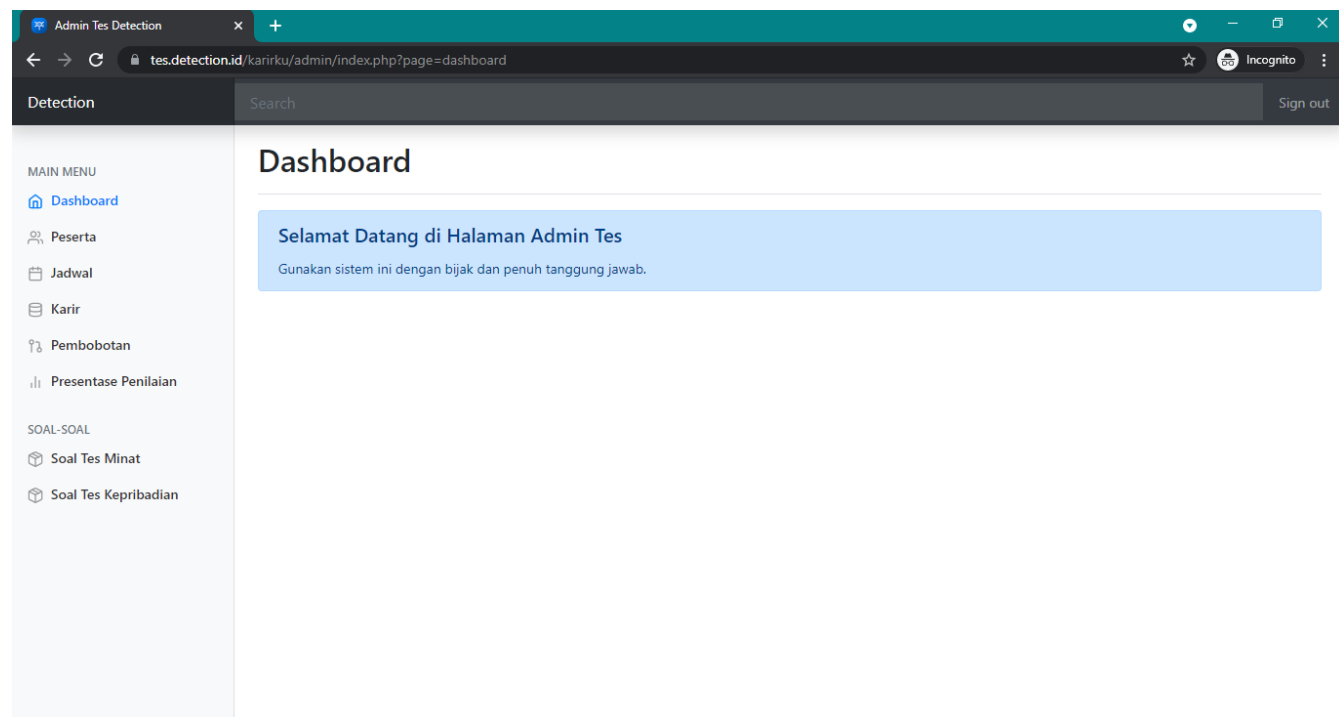

Gambar 3. Halaman Admin Tes

\subsection{Tes Minat}

Teori minat ini mengadaptasi dari Teori original Holland. John Holland mengatakan bahwa buku "Making Vocational Choices : A Theory of Vocational Personalities and Work Environments". Teori Holland mengemukakan enam lingkungan okupasional dan enam tipe kepribadian.Teori ini merupakan pendekatan yang paling banyak dipakai untuk membuat profil karir seseorang. Menurut teori ini, terdapat enam tipe kepribadian vocational, dari ke-enam tipe ini, seseorang dapat memiliki profil pilihan karir yang unik sesuai dengan minat dan kepribadiannya. Di bawah ini dijelaskan rincian setiap tipe sebagai berikut:

a. Realistic yaitu menyukai kegiatan yang mengandalkan kecekatan tangan dan fisik.

b. Investigative adalah menyukai kegiatan berfikir, melakukan percobaan, dan pengamatan.

c. Artistic adalah suka memunculkan ide, unik, dan memiliki jiwa seni.

d. Social adalah suka berinteraksi dengan orang lain, peduli, dan mau membantu orang lain.

e. Enterprising adalah suka menyampaikan gagasan, mempengaruhi orang lain, dan percaya diri dalam memimpin kelompok.

f. Conventional adalah detail, terorganisasi, sesuai prosedur, dan teliti.

Tes kepribadian berisi 21 soal. Tiap soal terdiri dari 6 pernyataan (stimulus) yang mewakili 6 aspek yang berbeda. Jawaban (aspek) yang dipilih akan mendapatkan nilai huruf "R" untuk Realistic, "I" untuk Investigative, "A" untuk Artistic, "S" untuk Social, "E" untuk Enterprising dan "C" untuk Conventional. Pembagian aspek pada tiap soal akan dijabarkan pada Tabel 1.

Tabel 1. Pembagian Aspek Minat

\begin{tabular}{ll}
\hline \multicolumn{1}{c}{ Pilihan Jawaban } & \multicolumn{1}{c}{ Aspek Tipe Minat } \\
\hline Pernyataan ke-1 nomor 1 sampai dengan 21 & Realistic (REA) \\
Pernyataan ke-2 nomor 1 sampai dengan 21 & Investigative (INV) \\
Pernyataan ke-3 nomor 1 sampai dengan 21 & Artistic (ART) \\
Pernyataan ke-4 nomor 1 sampai dengan 21 & Social (SOS) \\
Pernyataan ke-5 nomor 1 sampai dengan 21 & Enterprising (ENT) \\
Pernyataan ke-6 nomor 1 sampai dengan 21 & Conventional (CON) \\
\hline
\end{tabular}

Tes minat menggunakan metode paired comparison dengan model pilihan terarah (forced choice). Metode paired comparison merupakan model pelaksanaan dimana stimulus atau objek psikologis dibandingkan dalam suatu pasangan. Pembagian aspek pada tiap soal akan dijabarkan pada Tabel 1.

Pada Tabel 2 yang berisi tentang hasil tiap peserta tes berdasarkan dari tipe minat yang telah mereka pilih dari 21 pasang pernyataan. Nilai tipe minat berisi jumlah dari pilihan peserta tes yang merujuk kepada pilihan pernyataan aspek minat. 
Tabel 2. Hasil Tes Minat

\begin{tabular}{|c|c|c|c|c|c|c|}
\hline $\begin{array}{c}\text { No. } \\
\text { Peserta }\end{array}$ & REA & INV & ART & SOC & ENT & CON \\
\hline 1 & 2 & 2 & 0 & 3 & 3 & 11 \\
\hline 2 & 11 & 1 & 1 & 2 & 1 & 5 \\
\hline 3 & 2 & 0 & 0 & 8 & 8 & 3 \\
\hline 4 & 4 & 3 & 2 & 7 & 1 & 4 \\
\hline 5 & 2 & 6 & 7 & 1 & 2 & 3 \\
\hline 6 & 2 & 6 & 7 & 1 & 2 & 3 \\
\hline 7 & 1 & 2 & 5 & 10 & 3 & 0 \\
\hline 8 & 3 & 1 & 0 & 8 & 4 & 5 \\
\hline 9 & 1 & 6 & 2 & 7 & 5 & 0 \\
\hline 10 & 7 & 1 & 3 & 6 & 3 & 1 \\
\hline 11 & 4 & 2 & 1 & 11 & 0 & 3 \\
\hline 12 & 6 & 2 & 3 & 0 & 5 & 5 \\
\hline 13 & 2 & 1 & 4 & 7 & 4 & 3 \\
\hline 14 & 4 & 1 & 2 & 7 & 3 & 4 \\
\hline 15 & 3 & 2 & 2 & 4 & 2 & 8 \\
\hline 16 & 6 & 2 & 2 & 1 & 4 & 6 \\
\hline 17 & 3 & 2 & 1 & 12 & 2 & 1 \\
\hline 18 & 3 & 2 & 3 & 10 & 1 & 2 \\
\hline 19 & 6 & 2 & 2 & 10 & 1 & 0 \\
\hline 20 & 1 & 4 & 1 & 9 & 4 & 2 \\
\hline 21 & 2 & 2 & 3 & 8 & 3 & 3 \\
\hline 22 & 3 & 7 & 2 & 5 & 2 & 2 \\
\hline 23 & 2 & 4 & 1 & 10 & 4 & 0 \\
\hline 24 & 3 & 4 & 3 & 5 & 2 & 4 \\
\hline 25 & 0 & 11 & 0 & 7 & 3 & 0 \\
\hline 26 & 3 & 4 & 0 & 6 & 3 & 5 \\
\hline 27 & 1 & 2 & 5 & 6 & 4 & 3 \\
\hline 28 & 3 & 1 & 9 & 5 & 1 & 2 \\
\hline 29 & 7 & 2 & 2 & 5 & 4 & 1 \\
\hline 30 & 3 & 2 & 5 & 5 & 2 & 4 \\
\hline 31 & 3 & 2 & 2 & 6 & 2 & 6 \\
\hline 32 & 5 & 1 & 4 & 6 & 4 & 1 \\
\hline 33 & 6 & 4 & 3 & 4 & 2 & 2 \\
\hline 34 & 3 & 2 & 5 & 2 & 1 & 8 \\
\hline 35 & 10 & 5 & 3 & 0 & 2 & 1 \\
\hline 36 & 7 & 4 & 1 & 1 & 5 & 3 \\
\hline 37 & 8 & 7 & 1 & 1 & 1 & 3 \\
\hline 38 & 3 & 2 & 1 & 9 & 4 & 2 \\
\hline 39 & 4 & 1 & 2 & 4 & 6 & 4 \\
\hline 40 & 4 & 1 & 0 & 2 & 2 & 12 \\
\hline 41 & 8 & 5 & 2 & 2 & 2 & 2 \\
\hline 42 & 0 & 2 & 0 & 11 & 1 & 7 \\
\hline 43 & 3 & 3 & 1 & 6 & 3 & 5 \\
\hline 44 & 3 & 3 & 2 & 7 & 1 & 5 \\
\hline 45 & 4 & 3 & 3 & 4 & 2 & 5 \\
\hline 46 & 6 & 1 & 5 & 5 & 4 & 0 \\
\hline 47 & 1 & 2 & 2 & 9 & 0 & 7 \\
\hline 48 & 5 & 4 & 7 & 1 & 2 & 2 \\
\hline 49 & 2 & 2 & 3 & 8 & 5 & 1 \\
\hline 50 & 4 & 6 & 2 & 4 & 2 & 3 \\
\hline
\end{tabular}

Keterangan :

"REA" adalah aspek Realistic,

"INV" adalah aspek Investigative, 
"ART" adalah aspek Artistic,

"SOC" adalah aspek Social,

"ENT" adalah aspek Enterprising,

"CON" adalah aspek Conventional.

\subsection{Tes Kepribadian}

Teori minat ini dicetuskan oleh Dr. William Moulton Marston yang mempelajari emosi individu-individu yang dikategorikan normal dengan menulis sebuah buku yang berjudul “Emotions of Normal People”. Keempat emosi utama inilah yang sekarang dikenal sebagai DISC atau singkatan Dominance, Influence, Steadiness, dan Compliance, Berikut adalah rincian setiap tipe kepribadian:

a. Dominance adalah tipe yang memiliki sikap dominan, mereka cenderung mengutarakan segala hal secara langsung, mereka memiliki pengaruh yang kuat. Mereka memiliki kekuatan ego yang tinggi.

b. Influence adalah tipe yang antusias, memiliki kepercayaan diri yang tinggi, selalu optimis, banyak bicara, impulsive, emosional dan persuasive.

c. Steadiness adalah tipe pendengar yang baik, seorang yang posesif dan menenangkan. Mereka juga seseorang yang mudah ditebak dan sangat ramah.

d. Compliance adalah tipe yang sangat akurat dan seorang yang analitis. Mereka sangat cermat dan teliti.

Tes kepribadian berisi 40 soal. Tiap soal terdiri dari 4 pernyataan (stimulus) yang mewakili 4 aspek yang berbeda. Jawaban (aspek) yang dipilih akan mendapatkan nilai huruf "D" untuk Dominance, "I" untuk Influence, "S" untuk Steadiness dan "C" untuk Compliance. Pembagian aspek pada tiap soal akan dijabarkan pada Tabel 3 .

Tabel 3. Pembagian Aspek Kepribadian

\begin{tabular}{cl}
\hline \multicolumn{1}{c}{ Aspek } & Aspek Tipe Kepribadian \\
\hline Pernyataan ke-1 nomor 1 sampai dengan 40 & Dominance $($ DOM $)$ \\
Pernyataan ke-2 nomor 1 sampai dengan 40 & Influence $($ INF $)$ \\
Pernyataan ke-3 nomor 1 sampai dengan 40 & Steadiness $($ STE $)$ \\
Pernyataan ke-4 nomor 1 sampai dengan 40 & Compliance $($ COM $)$ \\
\hline
\end{tabular}

Tes kepribadian masih menggunakan metode yang sama dengan tes minat yaitu metode paired comparison dengan model pilihan terarah (forced choice). Stimulus yang dipilih adalah yang lebih menggambarkan karakeristik dirinya atau yang lebih disukai. Pembagian aspek pada tiap soal akan dijabarkan pada Tabel 3.

Pada Tabel 4 yang berisi tentang hasil tiap peserta tes berdasarkan dari tipe minat yang telah mereka pilih dari 40 pasang pernyataan. Nilai tipe minat berisi jumlah dari pilihan peserta tes yang merujuk kepada pilihan pernyataan aspek minat.

Tabel 4. Hasil Tes Kepribadian

\begin{tabular}{ccccc}
\hline $\begin{array}{c}\text { No. } \\
\text { Peserta }\end{array}$ & DOM & INF & STE & COM \\
\hline 1 & 2 & 2 & 0 & 3 \\
2 & 11 & 1 & 1 & 2 \\
3 & 2 & 0 & 0 & 8 \\
4 & 4 & 3 & 2 & 7 \\
5 & 2 & 6 & 7 & 1 \\
6 & 21 & 7 & 6 & 6 \\
7 & 20 & 4 & 8 & 8 \\
8 & 3 & 8 & 16 & 13 \\
9 & 16 & 16 & 5 & 3 \\
10 & 10 & 11 & 13 & 5 \\
11 & 9 & 6 & 16 & 9 \\
12 & 10 & 9 & 7 & 14 \\
13 & 7 & 11 & 16 & 6 \\
14 & 3 & 11 & 16 & 10 \\
15 & 7 & 11 & 10 & 12 \\
16 & 8 & 9 & 8 & 15 \\
17 & 9 & 8 & 15 & 8 \\
\hline & & 287 & &
\end{tabular}




\begin{tabular}{|c|c|c|c|c|}
\hline $\begin{array}{c}\text { No. } \\
\text { Peserta }\end{array}$ & DOM & INF & STE & COM \\
\hline 18 & 5 & 8 & 9 & 18 \\
\hline 19 & 19 & 16 & 4 & 1 \\
\hline 20 & 14 & 7 & 15 & 4 \\
\hline 21 & 11 & 10 & 11 & 8 \\
\hline 22 & 21 & 8 & 3 & 8 \\
\hline 23 & 3 & 12 & 17 & 8 \\
\hline 24 & 12 & 10 & 9 & 9 \\
\hline 25 & 11 & 6 & 9 & 14 \\
\hline 26 & 4 & 6 & 17 & 13 \\
\hline 27 & 13 & 12 & 7 & 8 \\
\hline 28 & 5 & 15 & 11 & 9 \\
\hline 29 & 5 & 9 & 18 & 8 \\
\hline 30 & 7 & 9 & 14 & 10 \\
\hline 31 & 3 & 7 & 16 & 14 \\
\hline 32 & 17 & 11 & 5 & 7 \\
\hline 33 & 12 & 14 & 9 & 5 \\
\hline 34 & 12 & 1 & 15 & 12 \\
\hline 35 & 11 & 4 & 6 & 19 \\
\hline 36 & 13 & 5 & 9 & 13 \\
\hline 37 & 4 & 7 & 18 & 11 \\
\hline 38 & 11 & 5 & 11 & 13 \\
\hline 39 & 15 & 10 & 12 & 3 \\
\hline 40 & 2 & 3 & 17 & 18 \\
\hline 41 & 15 & 10 & 9 & 6 \\
\hline 42 & 8 & 10 & 16 & 6 \\
\hline 43 & 0 & 39 & 1 & 0 \\
\hline 44 & 4 & 3 & 20 & 13 \\
\hline 45 & 12 & 10 & 12 & 6 \\
\hline 46 & 5 & 9 & 14 & 12 \\
\hline 47 & 9 & 5 & 12 & 14 \\
\hline 48 & 14 & 11 & 10 & 5 \\
\hline 49 & 14 & 6 & 12 & 8 \\
\hline 50 & 20 & 6 & 8 & 6 \\
\hline
\end{tabular}

Keterangan :

"DOM" adalah aspek Dominance, "INF" adalah aspek Influence, "STE" adalah aspek Steadiness,

"COM" adalah aspek Compliance.

\subsection{Profile Matching (GAP)}

Metode profile matching atau biasa disebut group algorithm programing (GAP) adalah suatu proses yang penting dalam menentukan kompetensi (kemampuan) yang diperlukan untuk suatu kriteria. Pada proses ini, secara umum merupakan proses membandingkan kompetensi individu dengan kompetensi yang menjadi kriteria agar dapat diketahui selisih kompetensinya.

Model yang digunakan dalam penilaian GAP pada penelitian ini adalah dengan model maksimasi, jadi kriteria acuan berada dalam range tertinggi agar mendapatkan pemain dengan kriteria tertinggi. Yang dimaksud dengan GAP disini adalah beda antara profil peserta tes dengan profil bidang karir atau dapat ditunjukkan pada Persamaan 1 :

$$
\text { GAP=Profil Terbaik-Profil Peserta Tes (1) }
$$

Pembobotan pada metode profile matching, merupakan nilai pasti yang tegas pada nilai tertentu karena nilai-nilai yang ada merupakan anggota himpunan tegas (crisp set). Di dalam himpunan tegas, keanggotaan suatu 
unsur di dalam himpunan dinyatakan secara tegas, apakah objek tersebut anggota himpunan atau bukan dengan menggunakan fungsi karakteristik. Setelah mendapatkan semua hasil dari pembobotan dari kriteria yang diinginkan, maka akan dicari nilai core factor dan secondary factor pada Persamaan 2 dan 3.

Penilaian nilai core factor :

Keterangan:

$$
N C F=\frac{\sum N C}{\sum I C}
$$

NCF : Nilai rata-rata core factor

NC : Jumlah total nilai core factor

IC : Jumlah total item core factor

Penilaian Nilai Secondary Factor:

$$
N S F=\frac{\sum N C}{\sum I C}
$$

Keterangan:

NCF : Nilai rata-rata secondary factor

NC : Jumlah total nilai secondary factor

IC : Jumlah total item secondary factor

Setelah mendapatkan semua hasil dari nilai core factor dan secondary factor, langkah selanjutnya adalah mencari nilai total berdasarkan Persamaan 4, yaitu :

Penilaian Nilai Total :

Keterangan:

$$
N T=(x) \% N C F+(x) N S F
$$

NT : Nilai total dari aspek/ kategori

(x)\% : Nilai persen yang diinputkan

NCF : Nilai rata-rata core factor

NSF : Nilai rata-rata secondary factor

Untuk nilai persen yang akan digunakan adalah $60 \%$ nilai minat untuk core factor dan $40 \%$ nilai kepribadian untuk secondary factor.

\subsubsection{Perhitungan Profile Matching (GAP)}

Pada penelitian ini, profil karir akan dicocokan dengan profil aspek minat dan aspek kepribadian dari masing-masing peserta tes. Profil tersebut terdiri dari aspek minat sebagai core factor dan tipe kepribadian sebagai secondary factor. Model yang digunakan dalam penilaian GAP ini adalah model maksimasi, yaitu kriteria yang menjadi acuan berada dalam range tertinggi agar mendapatkan hasil tertinggi.

Nilai pembobotan minat, yaitu selisih dari nilai objek (minat) dengan nilai dari kriteria (minat) yang ingin dicari atau dalam hal ini adalah nilai dari objek dengan nilai dari kriteria karir. Pembobotan minat dapat dilihat pada Tabel 5.

Tabel 5. Penilaian Bobot GAP Minat

\begin{tabular}{ccl}
\hline Selisih & Bobot & \multicolumn{1}{c}{ Keterangan } \\
\hline $5-6$ & 8 & Kompetensi sesuai kebutuhan \\
$3-4$ & 7 & Kompetensi kekurangan 1 level \\
$1-2$ & 6 & Kompetensi kekurangan 2 level \\
0 & 5 & Kompetensi kekurangan 3 level \\
$-1-(-3)$ & 4 & Kompetensi kekurangan 5 level \\
$-4-(-6)$ & 3 & Kompetensi kekurangan 9 level \\
$-7-(-9)$ & 2 & Kompetensi kekurangan 11 level \\
$-10-(-12)$ & 1 & Kompetensi kekurangan 14 level \\
$-13-(-15)$ & 0 & Tidak mempunyai kompetensi \\
\hline
\end{tabular}


Nilai pembobotan kepribadian, yaitu selisih dari nilai objek (kepribadian) dengan nilai dari kriteria (kepribadian) yang ingin dicari atau dalam hal ini adalah nilai dari objek dengan nilai dari kriteria karir. Pembobotan kepribadian dapat dilihat pada Tabel 6.

Tabel 6. Penilaian Bobot GAP Kepribadian

\begin{tabular}{ccl}
\hline Selisih & Bobot & Keterangan \\
\hline $11-15$ & 8 & Kompetensi sesuai kebutuhan \\
$6-10$ & 7 & Kompetensi kekurangan 1 level \\
$1-5$ & 6 & Kompetensi kekurangan 2 level \\
0 & 5 & Kompetensi kekurangan 3 level \\
$-1-(-5)$ & 4 & Kompetensi kekurangan 4 level \\
$-6-(-10)$ & 3 & Kompetensi kekurangan 9 level \\
$-11-(-15)$ & 2 & Kompetensi kekurangan 14 level \\
$-16-(-20)$ & 1 & Kompetensi kekurangan 19 level \\
$-21-(-25)$ & 0 & Tidak mempunyai kompetensi \\
\hline
\end{tabular}

\subsubsection{Perhitungan Profile Matching (GAP) untuk Karir Keguruan}

Pada tabel perhitungan berikut akan disimulasikan perhitungan dengan nilai target untuk karir Keguruan. Aspek nilai minat yang diambil untuk karir bidang Keguruan yaitu SOS, ENT dan CON. Aspek nilai kepribadian yang diambil untuk karir bidang Keguruan yaitu DOM, INF, dan STE. Setelah dilakukan penyeleksian nilai apa yang diambil maka untuk nilai aspek minat akan dikurangi nilai profil minat yaitu sebesar (-15) kemudian untuk aspek kepribadian dikurangi sebesar (-25) sehingga akan menjadi nilai GAP seperti yang tertera pada tabel 7 .

Tabel 7. Perhitungan GAP Pengajar

\begin{tabular}{|c|c|c|c|c|c|c|}
\hline \multirow{2}{*}{$\begin{array}{c}\text { No } \\
\text { Peserta }\end{array}$} & \multicolumn{3}{|c|}{ GAP Minat } & \multicolumn{3}{|c|}{ GAP Kepribadian } \\
\hline & SOS & ENT & CON & DOM & INF & STE \\
\hline 1 & -12 & -12 & -4 & -16 & -23 & -16 \\
\hline 2 & -13 & -14 & -10 & -9 & -18 & -17 \\
\hline 3 & -7 & -7 & -12 & -16 & -14 & -13 \\
\hline 4 & -8 & -14 & -11 & -16 & -13 & -12 \\
\hline 5 & -14 & -13 & -12 & -14 & -20 & -13 \\
\hline 6 & -5 & -12 & -15 & -4 & -18 & -19 \\
\hline 7 & -9 & -12 & -13 & -5 & -21 & -17 \\
\hline 8 & -7 & -11 & -10 & -22 & -17 & -9 \\
\hline 9 & -8 & -10 & -15 & -9 & -9 & -20 \\
\hline 10 & -9 & -12 & -14 & -15 & -14 & -12 \\
\hline 11 & -4 & -15 & -12 & -16 & -19 & -9 \\
\hline 12 & -15 & -10 & -10 & -15 & -16 & -18 \\
\hline 13 & -8 & -11 & -12 & -18 & -14 & -9 \\
\hline 14 & -8 & -12 & -11 & -22 & -14 & -9 \\
\hline 15 & -11 & -13 & -7 & -18 & -14 & -15 \\
\hline 16 & -14 & -11 & -9 & -17 & -16 & -17 \\
\hline 17 & -3 & -13 & -14 & -16 & -17 & -10 \\
\hline 18 & -5 & -14 & -13 & -20 & -17 & -16 \\
\hline 19 & -5 & -14 & -15 & -6 & -9 & -21 \\
\hline 20 & -6 & -11 & -13 & -11 & -18 & -10 \\
\hline 21 & -7 & -12 & -12 & -14 & -15 & -14 \\
\hline 22 & -10 & -13 & -13 & -4 & -17 & -22 \\
\hline 23 & -5 & -11 & -15 & -22 & -13 & -8 \\
\hline 24 & -10 & -13 & -11 & -13 & -15 & -16 \\
\hline 25 & -8 & -12 & -15 & -14 & -19 & -16 \\
\hline 26 & -9 & -12 & -10 & -21 & -19 & -8 \\
\hline 27 & -9 & -11 & -12 & -12 & -13 & -18 \\
\hline 28 & -10 & -14 & -13 & -20 & -10 & -14 \\
\hline 29 & -10 & -11 & -14 & -20 & -16 & -7 \\
\hline & & & 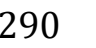 & & & \\
\hline
\end{tabular}




\begin{tabular}{ccccccc}
30 & -10 & -13 & -11 & -18 & -16 & -11 \\
31 & -9 & -13 & -9 & -22 & -18 & -9 \\
32 & -9 & -11 & -14 & -8 & -14 & -20 \\
33 & -11 & -13 & -13 & -13 & -11 & -16 \\
34 & -13 & -14 & -7 & -13 & -24 & -10 \\
35 & -15 & -13 & -14 & -14 & -21 & -19 \\
36 & -14 & -10 & -12 & -12 & -20 & -16 \\
37 & -14 & -14 & -12 & -21 & -18 & -7 \\
38 & -6 & -11 & -13 & -14 & -20 & -14 \\
39 & -11 & -9 & -11 & -10 & -15 & -13 \\
40 & -13 & -13 & -3 & -23 & -22 & -8 \\
41 & -13 & -13 & -13 & -10 & -15 & -16 \\
42 & -4 & -14 & -8 & -17 & -15 & -9 \\
43 & -9 & -12 & -10 & -25 & 14 & -24 \\
44 & -8 & -14 & -10 & -21 & -22 & -5 \\
45 & -11 & -13 & -10 & -13 & -15 & -13 \\
46 & -10 & -11 & -15 & -20 & -16 & -11 \\
47 & -6 & -15 & -8 & -16 & -20 & -13 \\
48 & -14 & -13 & -13 & -11 & -14 & -15 \\
49 & -7 & -10 & -14 & -11 & -19 & -13 \\
50 & -11 & -13 & -12 & -5 & -19 & -17 \\
\hline & & & & & &
\end{tabular}

Untuk menghitung nilai total diperlukan perhitungan dari core factor dan secondary factor. Untuk core factor akan merepresentasikan aspek minat dan secondary factor akan merepresentasikan aspek kepribadian. Pembagian prosentase untuk metode GAP ini adalah $60 \%$ untuk core factor dan $40 \%$ untuk secondary factor.

Untuk menghitung core factor yaitu pada tabel hasil GAP, hasil rata-rata dari kolom "bobot GAP minat", lalu hasil rata-rata tersebut dikalikan dengan $60 \%$. Untuk menghitung secondary factor yaitu pada tabel hasil GAP, hasil rata-rata dari kolom "gap kepribadian" (sebelah kanan kolom "bobot GAP minat"), lalu hasil ratarata tersebut dikalikan dengan $40 \%$. Lalu untuk menghitung nilai total yaitu dengan menjumlahkan hasil dari core factor dengan hasil dari seconday factor.

\subsubsection{Perhitungan Nilai Akhir untuk Karir Keguruan}

Tabel 8 berisi perhitungan core factor, secondary factor, dan nilai total GAP untuk karir di bidang keguruan tiap peserta tes:

Tabel 8. Perhitungan core factor dan secondary factor

\begin{tabular}{cccccc}
\hline $\begin{array}{c}\text { No } \\
\text { Peserta }\end{array}$ & $\begin{array}{c}\text { Core } \\
\text { Factor }\end{array}$ & $\begin{array}{c}\text { Secondary } \\
\text { Factor }\end{array}$ & $\mathbf{6 0 \%}$ & $\mathbf{4 0 \%}$ & Total \\
\hline 1 & 5.00 & 2.00 & 3.00 & 0.80 & 3.80 \\
2 & 3.00 & 2.00 & 1.80 & 0.80 & 2.60 \\
3 & 5.00 & 3.00 & 3.00 & 1.20 & 4.20 \\
4 & 3.00 & 3.00 & 1.80 & 1.20 & 3.00 \\
5 & 2.00 & 2.00 & 1.20 & 0.80 & 2.00 \\
6 & 4.00 & 3.00 & 2.40 & 1.20 & 3.60 \\
7 & 4.00 & 3.00 & 2.40 & 1.20 & 3.60 \\
8 & 5.00 & 2.00 & 3.00 & 0.80 & 3.80 \\
9 & 4.00 & 4.00 & 2.40 & 1.60 & 4.00 \\
10 & 3.00 & 3.00 & 1.80 & 1.20 & 3.00 \\
11 & 4.00 & 3.00 & 2.40 & 1.20 & 3.60 \\
12 & 4.00 & 2.00 & 2.40 & 0.80 & 3.20 \\
13 & 4.00 & 3.00 & 2.40 & 1.20 & 3.60 \\
14 & 4.00 & 3.00 & 2.40 & 1.20 & 3.60 \\
15 & 4.00 & 2.00 & 2.40 & 0.80 & 3.20 \\
16 & 3.00 & 1.00 & 1.80 & 0.40 & 2.20 \\
17 & 5.00 & 3.00 & 3.00 & 1.20 & 4.20 \\
18 & 4.00 & 1.00 & 2.40 & 0.40 & 2.80 \\
19 & 3.00 & 5.00 & 1.80 & 2.00 & 3.80 \\
20 & 5.00 & 4.00 & 3.00 & 1.60 & 4.60 \\
\hline
\end{tabular}




\begin{tabular}{|c|c|c|c|c|c|}
\hline $\begin{array}{c}\text { No } \\
\text { Peserta }\end{array}$ & $\begin{array}{c}\text { Core } \\
\text { Factor }\end{array}$ & $\begin{array}{c}\text { Secondary } \\
\text { Factor }\end{array}$ & $60 \%$ & $40 \%$ & Total \\
\hline 21 & 4.00 & 3.00 & 2.40 & 1.20 & 3.60 \\
\hline 22 & 4.00 & 3.00 & 2.40 & 1.20 & 3.60 \\
\hline 23 & 4.00 & 3.00 & 2.40 & 1.20 & 3.60 \\
\hline 24 & 4.00 & 3.00 & 2.40 & 1.20 & 3.60 \\
\hline 25 & 3.00 & 2.00 & 1.80 & 0.80 & 2.60 \\
\hline 26 & 5.00 & 2.00 & 3.00 & 0.80 & 3.80 \\
\hline 27 & 4.00 & 2.00 & 2.40 & 0.80 & 3.20 \\
\hline 28 & 3.00 & 3.00 & 1.80 & 1.20 & 3.00 \\
\hline 29 & 3.00 & 3.00 & 1.80 & 1.20 & 3.00 \\
\hline 30 & 4.00 & 3.00 & 2.40 & 1.20 & 3.60 \\
\hline 31 & 5.00 & 2.00 & 3.00 & 0.80 & 3.80 \\
\hline 32 & 3.00 & 3.00 & 1.80 & 1.20 & 3.00 \\
\hline 33 & 3.00 & 4.00 & 1.80 & 1.60 & 3.40 \\
\hline 34 & 3.00 & 3.00 & 1.80 & 1.20 & 3.00 \\
\hline 35 & 1.00 & 1.00 & 0.60 & 0.40 & 1.00 \\
\hline 36 & 3.00 & 2.00 & 1.80 & 0.80 & 2.60 \\
\hline 37 & 1.00 & 2.00 & 0.60 & 0.80 & 1.40 \\
\hline 38 & 5.00 & 2.00 & 3.00 & 0.80 & 3.80 \\
\hline 39 & 4.00 & 4.00 & 2.40 & 1.60 & 4.00 \\
\hline 40 & 6.00 & 2.00 & 3.60 & 0.80 & 4.40 \\
\hline 41 & 3.00 & 4.00 & 1.80 & 1.60 & 3.40 \\
\hline 42 & 5.00 & 3.00 & 3.00 & 1.20 & 4.20 \\
\hline 43 & 5.00 & 8.00 & 3.00 & 3.20 & 6.20 \\
\hline 44 & 4.00 & 3.00 & 2.40 & 1.20 & 3.60 \\
\hline 45 & 4.00 & 3.00 & 2.40 & 1.20 & 3.60 \\
\hline 46 & 3.00 & 3.00 & 1.80 & 1.20 & 3.00 \\
\hline 47 & 5.00 & 2.00 & 3.00 & 0.80 & 3.80 \\
\hline 48 & 2.00 & 4.00 & 1.20 & 1.60 & 2.80 \\
\hline 49 & 4.00 & 3.00 & 2.40 & 1.20 & 3.60 \\
\hline 50 & 3.00 & 3.00 & 1.80 & 1.20 & 3.00 \\
\hline
\end{tabular}

Jadi berdasarkan Tabel 8, maka telah didapatkan nilai akhir untuk karir pada bidang Keguruan pada kolom "Total". Untuk menghitung karir lainya maka akan digunakan cara perhitungan yang sama dengan perhitungan karir bidang keguruan dengan diganti aspek minat dan aspek kepribadian yang berkaitan dengan karir yang lain.

\subsubsection{Pengujian Hasil Akhir}

Berikut ini pada Tabel 9 berisi daftar karir dari hasil tiap-tiap peserta tes, berdasarkan hasil dari metode GAP dengan pakar. Karir yang menjadi rekomendasi peserta tes dari metode GAP, diambil dari 6 karir. Hasil rekomendasi karir dianggap valid atau berhasil sama apabila ada minimal 3 rekomendasi karir yang sama dengan rekomendasi dari pakar. Pada kolom "Status" adalah berapa karir yang sesuai dengan pakar.

Tabel 9. Pengujian Hasil Karir

\begin{tabular}{cllc}
\hline $\begin{array}{c}\text { No. } \\
\text { Peserta }\end{array}$ & \multicolumn{1}{c}{ Hasil Pakar } & \multicolumn{1}{c}{ Hasil GAP } & Status \\
\hline \multirow{2}{*}{1} & Kedokteran, Pariwisata, Ilmu & Kedokteran, Pariwisata, Ilmu & Semua \\
& Keperawatan, Farmasi, Keguruan, Gizi. & Keperawatan, Farmasi, Keguruan, Gizi. & Valid \\
& Kesehatan Masyarakat, Kedinasan, & Kesehatan Masyarakat, Kedinasan, & Semua \\
2 & Kearsipan, Gizi, Kesehatan Lingkungan, & Kearsipan, Gizi, Kesehatan Lingkungan, & Valid \\
& Ilmu Keperawatan. & Ilmu Keperawatan. & 5 Valid \\
3 & Gizi, Keguruan, Psikologi, Pariwisata, & Gizi, Keguruan, Kedokteran, Pariwisata, & Semua \\
& Ilmu Keperawatan, Peternakan. & Ilmu Keperawatan, Peternakan. & Valid \\
4 & Gizi, Kedokteran, Pariwisata, Peternakan, & Gizi, Kedokteran, Pariwisata, Peternakan, & Seguruan, Ilmu Keperawatan. \\
& Keguruan, Ilmu Keperawatan. & Kegua & Semua \\
& Teknik Informatika, Statistika, Teknik & Teknik Informatika, Statistika, Teknik & Valid
\end{tabular}




\begin{tabular}{|c|c|c|c|}
\hline $\begin{array}{c}\text { No. } \\
\text { Peserta }\end{array}$ & Hasil Pakar & Hasil GAP & Status \\
\hline & MIPA. & MIPA. & \\
\hline 6 & $\begin{array}{l}\text { Kedokteran, Pariwisata, Keguruan, Gizi, } \\
\text { Psikologi, Kesehatan Masyarakat. }\end{array}$ & $\begin{array}{l}\text { Kedokteran, Pariwisata, Keguruan, Gizi, } \\
\text { Psikologi, Kesehatan Masyarakat. }\end{array}$ & $\begin{array}{c}\text { Semua } \\
\text { Valid }\end{array}$ \\
\hline 7 & $\begin{array}{l}\text { Kesehatan Masyarakat, Pariwisata, Gizi, } \\
\text { Kedokteran, Kesehatan Lingkungan, } \\
\text { Psikologi. }\end{array}$ & $\begin{array}{l}\text { Kesehatan Masyarakat, Pariwisata, Gizi, } \\
\text { Kedokteran, Kesehatan Lingkungan, } \\
\text { Psikologi. }\end{array}$ & $\begin{array}{l}\text { Semua } \\
\text { Valid }\end{array}$ \\
\hline 8 & $\begin{array}{l}\text { Keguruan, Ilmu Keperawatan, Peternakan, } \\
\text { Gizi, Teknik Lingkungan, Pariwisata. }\end{array}$ & $\begin{array}{l}\text { Keguruan, Ilmu Keperawatan, Peternakan, } \\
\text { Gizi, Teknik Lingkungan, Pariwisata. }\end{array}$ & $\begin{array}{c}\text { Semua } \\
\text { Valid }\end{array}$ \\
\hline 9 & $\begin{array}{l}\text { Kesehatan Masyarakat, Pariwisata, } \\
\text { Psikologi, Kedokteran, Kesehatan } \\
\text { Lingkungan, Gizi. }\end{array}$ & $\begin{array}{l}\text { Kesehatan Masyarakat, Pariwisata, } \\
\text { Psikologi, Kedokteran, Kesehatan } \\
\text { Lingkungan, Gizi }\end{array}$ & $\begin{array}{l}\text { Semua } \\
\text { Valid }\end{array}$ \\
\hline 10 & $\begin{array}{l}\text { Keguruan, Peternakan, Kesehatan, Ilmu } \\
\text { Keperawatan, Gizi, Kesehatan } \\
\text { Lingkungan. }\end{array}$ & $\begin{array}{l}\text { Keguruan, Peternakan, Kesehatan, Ilmu } \\
\text { Keperawatan, Gizi, Kesehatan } \\
\text { Lingkungan. }\end{array}$ & $\begin{array}{l}\text { Semua } \\
\text { Valid }\end{array}$ \\
\hline 11 & $\begin{array}{l}\text { Gizi, Peternakan, Teknik Lingkungan, } \\
\text { Pertanian } \\
\text { Ilmu Keperawatan, Kedokteran. }\end{array}$ & $\begin{array}{l}\text { Gizi, Keguruan, Teknik Lingkungan, } \\
\text { Peternakan } \\
\text { Ilmu Keperawatan, Kedokteran. }\end{array}$ & 5 Valid \\
\hline 12 & $\begin{array}{l}\text { Teknik Informatika, Statistika, Akutansi, } \\
\text { Teknik Geodesi, Teknik Elektronik, } \\
\text { Kearsipan. }\end{array}$ & $\begin{array}{l}\text { Gizi, Ilmu Keperawatan, Kedokteran, } \\
\text { Pariwisata } \\
\text { Teknik Informatika, Kearsipan. }\end{array}$ & 2 Valid \\
\hline 13 & $\begin{array}{l}\text { Keguruan, Psikologi, Kedokteran, } \\
\text { Pariwisata, Peternakan, Ilmu } \\
\text { Keperawatan. }\end{array}$ & $\begin{array}{l}\text { Keguruan, Gizi, Kedokteran, Pariwisata, } \\
\text { Peternakan } \\
\text { Ilmu Keperawatan. }\end{array}$ & 5 Valid \\
\hline 14 & $\begin{array}{l}\text { Keguruan, Pariwisata, Kedokteran, Gizi, } \\
\text { Ilmu Keperawatan, Peternakan }\end{array}$ & $\begin{array}{l}\text { Keguruan, Pariwisata, Kedokteran, Gizi, } \\
\text { Ilmu Keperawatan, Peternakan }\end{array}$ & $\begin{array}{l}\text { Semua } \\
\text { Valid }\end{array}$ \\
\hline 15 & $\begin{array}{l}\text { Gizi, Ilmu Keperawatan, Kedokteran, } \\
\text { Pariwisata } \\
\text { Keguruan, Kedinasan. }\end{array}$ & $\begin{array}{l}\text { Gizi, Ilmu Keperawatan, Kedokteran, } \\
\text { Pariwisata } \\
\text { Keguruan, Kedinasan. }\end{array}$ & $\begin{array}{c}\text { Semua } \\
\text { Valid }\end{array}$ \\
\hline 16 & $\begin{array}{l}\text { Ilmu Keperawatan, Gizi, Kedokteran, } \\
\text { Farmasi } \\
\text { Kearsipan, Kedinasan }\end{array}$ & $\begin{array}{l}\text { Ilmu Keperawatan, Gizi, Kedokteran, } \\
\text { Pariwisata } \\
\text { Kearsipan, Kedinasan }\end{array}$ & 5 Valid \\
\hline 17 & $\begin{array}{l}\text { Kesehatan Masyarakat, Psikologi, } \\
\text { Kesehatan Lingkungan, Keguruan, Ilmu } \\
\text { Keperawatan, Komunikasi }\end{array}$ & $\begin{array}{l}\text { Gizi, Peternakan, Teknik Lingkungan, } \\
\text { Keguruan } \\
\text { Ilmu Keperawatan, Kesehatan Lingkungan }\end{array}$ & 3 Valid \\
\hline 18 & $\begin{array}{l}\text { Teknik Lingkungan, Ilmu Keperawatan, } \\
\text { Enterpreneur, Desainer, Pekerja Seni, } \\
\text { Pariwisata }\end{array}$ & $\begin{array}{l}\text { Teknik Lingkungan, Ilmu Keperawatan, } \\
\text { Enterpreneur, Desainer, Pekerja Seni, } \\
\text { Pariwisata }\end{array}$ & $\begin{array}{l}\text { Semua } \\
\text { Valid }\end{array}$ \\
\hline 19 & $\begin{array}{l}\text { Kesehatan Lingkungan, Kesehatan } \\
\text { Masyarakat } \\
\text { Psikologi, Ilmu Keperawatan, Keguruan, } \\
\text { Gizi }\end{array}$ & $\begin{array}{l}\text { Kesehatan Lingkungan, Kesehatan } \\
\text { Masyarakat } \\
\text { Psikologi, Ilmu Keperawatan, Keguruan, } \\
\text { Gizi }\end{array}$ & $\begin{array}{l}\text { Semua } \\
\text { Valid }\end{array}$ \\
\hline 20 & $\begin{array}{l}\text { Gizi, Keguruan, Kesehatan Masyarakat, } \\
\text { Peternakan } \\
\text { Pariwisata, Kedokteran. }\end{array}$ & $\begin{array}{l}\text { Gizi, Keguruan, Kesehatan Masyarakat, } \\
\text { Peternakan } \\
\text { Pariwisata, Kedokteran. }\end{array}$ & $\begin{array}{c}\text { Semua } \\
\text { Valid }\end{array}$ \\
\hline 21 & $\begin{array}{l}\text { Keguruan, Gizi, Pariwisata, Kedokteran, } \\
\text { Ilmu Keperawatan, Pekerja Seni. } \\
\text { Kesehatan Lingkungan, Kesehatan }\end{array}$ & $\begin{array}{l}\text { Keguruan, Gizi, Pariwisata, Kedokteran, } \\
\text { Ilmu Keperawatan, Pekerja Seni. } \\
\text { Kesehatan Lingkungan, Kesehatan }\end{array}$ & $\begin{array}{l}\text { Semua } \\
\text { Valid } \\
\text { Semua }\end{array}$ \\
\hline 22 & $\begin{array}{l}\text { Masyarakat, Psikologi, Kedokteran, } \\
\text { Pariwisata, Gizi. }\end{array}$ & $\begin{array}{l}\text { Masyarakat, Psikologi, Kedokteran, } \\
\text { Pariwisata, Gizi. }\end{array}$ & Valid \\
\hline 23 & $\begin{array}{l}\text { Peternakan, Pertanian, Pariwisata, } \\
\text { Keguruan } \\
\text { Enterpreneur, Teknik Lingkungan }\end{array}$ & $\begin{array}{l}\text { Peternakan, Gizi, Keguruan, Pariwisata, } \\
\text { Kedokteran } \\
\text { Teknik Lingkungan }\end{array}$ & 4 Valid \\
\hline 24 & $\begin{array}{l}\text { Kedokteran, Kedinasan, Psikologi, } \\
\text { Kesehatan Lingkungan, Kesehatan } \\
\text { Masyarakat, Keguruan }\end{array}$ & $\begin{array}{l}\text { Kedokteran, Pariwisata, Gizi, Kesehatan } \\
\text { Lingkungan } \\
\text { Kesehatan Masyarakat, Keguruan }\end{array}$ & 4 Valid \\
\hline 25 & Komunikasi, Kedokteran, Kesehatan, & Pariwisata, Kedokteran, Kesehatan, & 5 Valid \\
\hline
\end{tabular}




\begin{tabular}{|c|c|c|c|}
\hline $\begin{array}{c}\text { No. } \\
\text { Peserta }\end{array}$ & Hasil Pakar & Hasil GAP & Status \\
\hline & Psikologi & Psikologi & \\
\hline & Peternakan, Kesehatan Lingkungan & Peternakan, Kesehatan Lingkungan & \\
\hline & Pertanian, Gizi, Teknik Lingkungan, Ilmu & Pertanian, Gizi, Teknik Lingkungan, Ilmu & Semua \\
\hline 26 & Keperawatan, Kedokteran, Pariwisata & Keperawatan, Kedokteran, Pariwisata & Valid \\
\hline 27 & $\begin{array}{l}\text { Pariwisata, Kedokeran, Keguruan, Gizi, } \\
\text { Enterpreneur, Desainer }\end{array}$ & $\begin{array}{l}\text { Pariwisata, Kedokeran, Keguruan, Gizi, } \\
\text { Enterpreneur, Desainer }\end{array}$ & $\begin{array}{l}\text { Semua } \\
\text { Valid }\end{array}$ \\
\hline 28 & $\begin{array}{l}\text { Enterpreneur, Desainer, Pekerja Seni, } \\
\text { Pariwisata } \\
\text { Gizi, Teknik Elektronika }\end{array}$ & $\begin{array}{l}\text { Enterpreneur, Desainer, Pekerja Seni, } \\
\text { MIPA, Gizi, Teknik Elektronika }\end{array}$ & 5 Valid \\
\hline 29 & $\begin{array}{l}\text { Gizi, Peternakan, Teknik Lingkungan, } \\
\text { Ilmu Keperawatan, Keguruan, Kesehatan } \\
\text { Masyarakat }\end{array}$ & $\begin{array}{l}\text { Gizi, Peternakan, Teknik Lingkungan, } \\
\text { Ilmu Keperawatan, Keguruan, Kesehatan } \\
\text { Masyarakat }\end{array}$ & $\begin{array}{l}\text { Semua } \\
\text { Valid }\end{array}$ \\
\hline & Kesehatan Masyarakat, Ilmu & Gizi, Ilmu Keperawatan, MIPA, & 2 Valid \\
\hline 30 & $\begin{array}{l}\text { Keperawatan, Keguruan } \\
\text { Kedokteran, Komunikasi, Psikologi }\end{array}$ & $\begin{array}{l}\text { Kedokteran, Teknik Informatika, Teknik } \\
\text { Lingkungan }\end{array}$ & \\
\hline 31 & $\begin{array}{l}\text { Gizi, Ilmu Keperawatan, Keguruan, } \\
\text { Teknik Lingkungan, Pariwisata, } \\
\text { Kedokteran }\end{array}$ & $\begin{array}{l}\text { Gizi, Ilmu Keperawatan, Keguruan, } \\
\text { Teknik Lingkungan, Pariwisata, } \\
\text { Kedokteran }\end{array}$ & $\begin{array}{l}\text { Semua } \\
\text { Valid }\end{array}$ \\
\hline 32 & $\begin{array}{l}\text { Gizi, Kesehatan Masyarakat, Keguruan, } \\
\text { Pariwisata } \\
\text { Kedokteran, Psikologi }\end{array}$ & $\begin{array}{l}\text { Gizi, Kesehatan Masyarakat, Keguruan, } \\
\text { Pariwisata } \\
\text { Kedokteran, Psikologi }\end{array}$ & $\begin{array}{l}\text { Semua } \\
\text { Valid }\end{array}$ \\
\hline 33 & $\begin{array}{l}\text { Kesehatan Lingkungan, Kesehatan } \\
\text { Masyarakat, Gizi } \\
\text { Peternakan, Kedokteran, Psikologi }\end{array}$ & $\begin{array}{l}\text { Kesehatan Lingkungan, Kesehatan } \\
\text { Masyarakat, Gizi } \\
\text { Peternakan, Kedokteran, Teknik } \\
\text { Informatika }\end{array}$ & 5 Valid \\
\hline 34 & $\begin{array}{l}\text { Kearsipan, Teknik Informatika, } \\
\text { Kedinasan, MIPA } \\
\text { Keguruan, Akutansi }\end{array}$ & $\begin{array}{l}\text { Kearsipan, Gizi, Kedinasan, MIPA, } \\
\text { Keguruan, } \\
\text { Akutansi }\end{array}$ & 5 Valid \\
\hline & Teknik Informatika, MIPA, Teknik & Teknik Informatika, MIPA, Teknik & Semua \\
\hline 35 & $\begin{array}{l}\text { Elektronika } \\
\text { Pembangunan Wilayah, Teknik Geodesi, } \\
\text { Teknik Kimia }\end{array}$ & $\begin{array}{l}\text { Elektronika } \\
\text { Pembangunan Wilayah, Teknik Geodesi, } \\
\text { Teknik Kimia }\end{array}$ & Valid \\
\hline 36 & $\begin{array}{l}\text { Gizi, Kedokteran, Bidang Hukum, Ilmu } \\
\text { Keperawatan } \\
\text { Kesehatan Masyarakat, Peternakan }\end{array}$ & $\begin{array}{l}\text { Gizi, Kedokteran, Pariwisata, Ilmu } \\
\text { Keperawatan } \\
\text { Kesehatan Masyarakat, Peternakan }\end{array}$ & 5 Valid \\
\hline & MIPA, Teknik Industri, Teknik & MIPA, Teknik Industri, Teknik & Semua \\
\hline 37 & $\begin{array}{l}\text { Elektronika, Teknik Fisika, Teknik } \\
\text { Geodesi, Teknik Informatika }\end{array}$ & $\begin{array}{l}\text { Elektronika, Teknik Fisika, Teknik } \\
\text { Geodesi, Teknik Informatika }\end{array}$ & Valid \\
\hline 38 & $\begin{array}{l}\text { Psikologi, Kedokteran, Pariwisata, } \\
\text { Keguruan, Ilmu Keperawatan, Peternakan. }\end{array}$ & $\begin{array}{l}\text { Gizi, Kedokteran, Pariwisata, Keguruan, } \\
\text { Ilmu Keperawatan, Peternakan }\end{array}$ & 5 Valid \\
\hline 39 & $\begin{array}{l}\text { Gizi, Keguruan, Psikologi, Pariwisata, } \\
\text { Kesehatan Masyarakat, Peternakan }\end{array}$ & $\begin{array}{l}\text { Gizi, Keguruan, Kedokteran, Pariwisata, } \\
\text { Kesehatan Masyarakat, Peternakan }\end{array}$ & 5 Valid \\
\hline 40 & $\begin{array}{l}\text { Kearsipan, Ilmu Keperawatan, Kedinasan, } \\
\text { Farmasi } \\
\text { Akutansi, Gizi }\end{array}$ & $\begin{array}{l}\text { Kearsipan, Ilmu Keperawatan, Kedinasan, } \\
\text { Farmasi } \\
\text { Akutansi, Gizi }\end{array}$ & $\begin{array}{l}\text { Semua } \\
\text { Valid }\end{array}$ \\
\hline 41 & $\begin{array}{l}\text { Teknik Kimia, Psikologi, Gizi, Pertanian, } \\
\text { Peternakan, Farmasi }\end{array}$ & $\begin{array}{l}\text { Kesehatan Lingkungan, Kesehatan } \\
\text { Masyarakat } \\
\text { Gizi, Pariwisata, Peternakan, Kedokteran }\end{array}$ & 2 Valid \\
\hline 42 & $\begin{array}{l}\text { Keguruan, Gizi, Psikologi, Pariwisata, } \\
\text { Ilmu Keperawatan, Peternakan. }\end{array}$ & $\begin{array}{l}\text { Keguruan, Gizi, Kedokteran, Pariwisata, } \\
\text { Ilmu Keperawatan, Peternakan. }\end{array}$ & 5 Valid \\
\hline 43 & $\begin{array}{l}\text { Ilmu Keperawatan, Kesehatan } \\
\text { Masyarakat, Bidang Hukum, Psikologi, } \\
\text { Gizi, Kesehatan. }\end{array}$ & $\begin{array}{l}\text { Ilmu Keperawatan, Kesehatan Masyarakat, } \\
\text { Pariwisata, Peternakan, Gizi, Kesehatan. }\end{array}$ & 4 Valid \\
\hline 44 & $\begin{array}{l}\text { Teknik Lingkungan, Peternakan, Gizi, } \\
\text { Akutansi } \\
\text { Teknik Geodesi, Teknik Industri. }\end{array}$ & $\begin{array}{l}\text { Teknik Lingkungan, Peternakan, Gizi, } \\
\text { Akutansi } \\
\text { Teknik Geodesi, MIPA. }\end{array}$ & 5 Valid \\
\hline
\end{tabular}




\begin{tabular}{|c|c|c|c|}
\hline $\begin{array}{c}\text { No. } \\
\text { Peserta }\end{array}$ & Hasil Pakar & Hasil GAP & Status \\
\hline 45 & $\begin{array}{l}\text { Gizi, Kedokteran, Kedinasan, Keguruan, } \\
\text { Psikologi } \\
\text { Bidang Hukum. }\end{array}$ & $\begin{array}{l}\text { Gizi, Kedokteran, Pariwisata, Keguruan, } \\
\text { Peternakan } \\
\text { Kesehatan Lingkungan. }\end{array}$ & 3 Valid \\
\hline 46 & $\begin{array}{l}\text { Enterprenur, Komunikasi, Sosial Politik, } \\
\text { Keguruan } \\
\text { Arsitektur, Pembangunan Wilayah. }\end{array}$ & $\begin{array}{l}\text { Gizi, Ilmu Keperawatan, Peternakan, } \\
\text { Teknik Informatika, Teknik Elektronika, } \\
\text { Teknik Lingkungan. }\end{array}$ & 0 Valid \\
\hline 47 & $\begin{array}{l}\text { Kearsipan, Statistika, Gizi, Farmasi, } \\
\text { Akutansi } \\
\text { Teknik Lingkungan. }\end{array}$ & $\begin{array}{l}\text { Pariwisata, Kedokteran, Gizi, Keguruan, } \\
\text { Ilmu Keperawatan, Teknik Lingkungan. }\end{array}$ & 2 Valid \\
\hline 48 & $\begin{array}{l}\text { MIPA, Teknik Informatika, Teknik } \\
\text { Elektronika } \\
\text { Arsitektur, Bidang Hukum, Statistika. }\end{array}$ & $\begin{array}{l}\text { MIPA, Teknik Informatika, Teknik } \\
\text { Elektronika, Arsitektur, Bidang Hukum, } \\
\text { Statistika }\end{array}$ & $\begin{array}{c}\text { Semua } \\
\text { Valid }\end{array}$ \\
\hline 49 & $\begin{array}{l}\text { Keguruan, Gizi, Kedokteran, Pariwisata, } \\
\text { Pekerja Seni, Desainer }\end{array}$ & $\begin{array}{l}\text { Keguruan, Gizi, Kedokteran, Pariwisata, } \\
\text { Pekerja Seni } \\
\text { Desainer }\end{array}$ & $\begin{array}{l}\text { Semua } \\
\text { Valid }\end{array}$ \\
\hline 50 & $\begin{array}{l}\text { Kedokteran, Pariwisata, Kesehatan } \\
\text { Masyarakat, } \\
\text { Kesehatan Lingkungan, Gizi, Psikologi. }\end{array}$ & $\begin{array}{l}\text { Kedokteran, Pariwisata, Kesehatan } \\
\text { Masyarakat, } \\
\text { Kesehatan Lingkungan, Gizi, Psikologi. }\end{array}$ & $\begin{array}{l}\text { Semua } \\
\text { Valid }\end{array}$ \\
\hline
\end{tabular}

Pada Tabel 9, terdapat hasil dari perbandingan report 50 peserta tes sebagai berikut:

a. Terdapat 27 peserta tes dengan jumlah semua karir sesuai dengan pakar.

b. Terdapat 13 peserta tes dengan jumlah 5 karir yang sesuai pakar.

c. Terdapat 3 peserta tes dengan jumlah 4 karir yang sesuai pakar.

d. Terdapat 2 peserta tes dengan jumlah 3 karir yang sesuai pakar.

e. Tidak ada peserta tes yang menghasilkan rekomendasi 1 karir yang sesuai pakar.

f. Terdapat 1 peserta tes dengan tidak ada rekomendasi semua karir yang sesuai pakar.

\section{KESIMPULAN}

Sistem pakar dengan menggunakan metode profile matching atau GAP dapat digunakan sebagai salah satu alternatif tes pemetaan karir. Adapun kesimpulan akhir dari sistem pakaar ini adalah sebagai berikut:

a. Pengembangan sistem pakar yang digunakan untuk membantu seseorang dalam mengetahui karir yang cocok dengan minat dan kepribadiannya.

b. Dari total 50 peserta tes, $90 \%$ atau 45 orang peserta tes rekomendasi karir yang dihasilkan oleh sistem dari metode GAP cocok dengan hasil manual dari pakar, sedangkan $10 \%$ atau 5 orang peserta tes rekomendasi karir tidak sesuai dengan hasil manual pakar.

c. Data karir yang berjumlah 31 masih bisa ditambah sesuai dengan karir yang potensial untuk ditekuni di masa depan. Untuk Sementara jumlah karir hanya berjumlah 31, karena rekomendasi dari pakar dan hampir sudah mencakup data karir yang ada.

d. Rekomendasi jurusan dari metode GAP dapat menggantikan peran sesi konesling dan konselor/psikolog dalam memberikan rekomendasi karir yanag sesuai dengan sisi psikologi peserta tes.

\section{SARAN}

Tahap penilaian atau hasil rekomendasi karir ini masih sebatas dari aspek psikologis peserta tes, belum dikombinasikan dengan hasil akademik peserta tes. Perlu adanya tambahan informasi atau saran pengganti konseling pada report apabila peserta tes tersebut mempunyai nilai kognitif yang kurang dibandingkan dengan karir yang dia inginkan. Saran bagi penelitian selanjutnya adalah :

a. Membuat perbandingan antara metode yang digunakan pada penelitian ini (GAP) dengan metode yang lain.

b. Membuat perbandingan antara penelitian ini dengan penelitian yang serupa (menghasilkan rekomendasi karir atau sikap kerja atau tingkat kecerasan) namun dengan teori psikologi yang berbeda untuk mendapatkan teori yang tepat untuk memberikan rekomendasi karir untuk peserta tes. 


\section{DAFTAR PUSTAKA}

[1] P. N, Psikologi Pendidikan, Bandung: Remaja Rosdakarya, 2010.

[2] W. Wawan and V. V. Tobing, "Aplikasi Sistem Pakar Tes Kepribadian Berbasis Web," Jurnal Informatika, Sistem Kendali dan Komputer, Vols. Volume 5, No 2, pp. 99-103, 2016.

[3] A. H. Alkhelil, "The Relationship between Personality Traits and Career Choice: A Case Study of Secondary School Students.," International Journal of Academic Research in Progressive Education and Development, vol. 5, pp. 139-152, 2016.

[4] F. K. Hidayat and S. N. Wahyuni, "PENDETEKSIAN MINAT DAN BAKAT MENGGUNAKAN METODE RIASEC," Indonesian Journal of Business Intelligence, vol. 2, no. 1, pp. 32-39, 2019.

[5] D. M. Wijaya and W. K. Raharja, "IMPLEMENTASI METODE FORWARD CHAINING PADA SISTEM," vol. 6, pp. 14-20, 2015.

[6] A. S. Jati, K. and H. A. Fatta, "Pengembangan Prototype Tes Psikologi Perencanaan Karir Siswa SMA," Citec Journal, vol. 5, no. 1, pp. 58-70, 2018.

[7] C. K. E. Goni, O. Henry and L. David, "Gambaran kepribadian berdasarkan tes Disc mahasiswa Fakultas," Jurnal e-Biomedik (eBm), vol. 4, no. 2, pp. -, 2016.

[8] I. N. Farida and R. Firliana, "Implementasi Metode Profile Matching Untuk Evaluasi Potensi Akademik Penjurusan Siswa MAN 2 Kota Kediri," JURNAL INFORTEL, vol. 8, no. 2, pp. 156-163, 2016.

[9] T. A. A. Toibin and A. S. Purnomo, "Sistem Pakar Pengembangan Skala Minat Karir Mahasiswa Dengan Inferensi Fuzzy," Prosiding Seminar Nasional Multimedia \& Artificial Intelligence 2018, vol. 1, no. -, pp. 156-162, 2018.

[10] D. P. Indah, A. and U. Radiyah, "SISTEM PAKAR DETEKSI KARAKTERISTIK DAN KEPRIBADIAN DIRI MENGGUNAKAN METODE FORWARD CHAINING," JIMP - Jurnal Informatika Merdeka Pasuruan, vol. 3, no. 1, pp. 34-43, 2018. 